\title{
第14回 日本爬虫両棲類学会大会記録
}

\author{
昭和50年 9 月 12 日 於新潟市, 日本歯科大学新潟歯学部
}

The 14th Annual Meeting of the Herpetological Society of Japan

September 12, 1975 at Niigata, Nippon Dental College

\section{大会記 事}

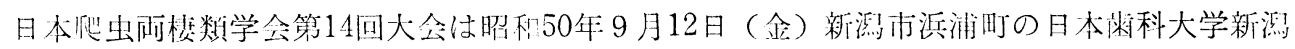

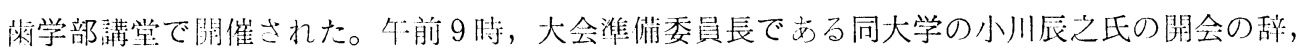
次いで吉閌敏雄氏から運営上の諸注意がのべられ会がはじまった。講演は全部で19題で, 座韦 にはゴリスリチード氏・小田幸雨氏・岩沢久彰氏が順次につよめた。年後 1 咕10分から50分間

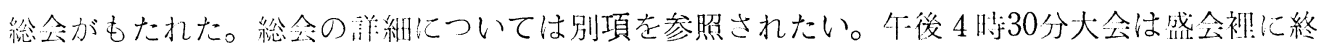

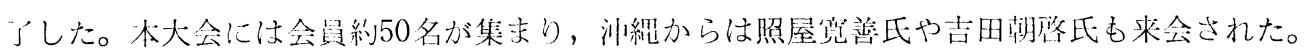

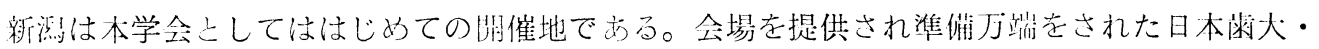

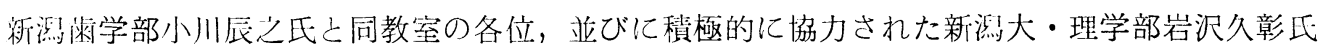
上同教室の各位に対し，出席した会員一同は媣い感謝の念をおぼえた。とくに新鼬歯学部解剖 学教室は開校 4 年目というが立派な設俑の整った建物は見事である。大会終了後有志のものは 学内食堂で懇親会をもち，友情を深め合った。

\section{講 演 要旨}

\section{1. 脳下垂体前葉摘出トノサマガエルにおける精巣組織の変化の季節差}

岩沢久彰・東城㴋介（新潟大・理・生物）

Effect of hypophysectomy on testicular histology in spring and autumn frogs, Rana nigromaculata. Hisaaki Iwasawa and Yôsuke Tôjô (Biol. Inst., Fac. Sci., Niigata Univ.)

新溜県北部の金塚で 5 月（シリーズ1）と10月（シリーズ2）に採集したトノサマガエルの 雄成体の脳下垂体前葉を摘出し， $25^{\circ} \mathrm{C} ， 12$ 年間照明で飼奇して, 精巣のうける影響を組織学的 に众討した。シリーズ 1 では摘出の $10 ・ 20 ・ 40$ 日後に，シリーズ 2 では 40 日後に固定した。観 察に用いた㑉体数は 2 シリーズで対照区・実験区を合せて $57 匹 ，$ 実験開始の時期はシリーズ 1 では繁列期の直後, シリーズ 2 では冬眠直前にあたる。シリーズ1では実験開始時には細精管 は精子でみたされ，野外ではやがててれらは放出されて，後に精子形成が活発におてるが，飼 育個体では対照区・実験区之もに精子の放出はわずかで，精子形成は明らかにおくれていた。 シリーズ 2 では実験開始時多くの精子ができており，精子形成活性度は著しく低下している。 
40日後において対照区では精子の他に第 2 精原細胞の増数がみられたが，実験区ではてれは殆 んよ゙みられなかった。細精管の直径は雨シリーズとも脳下垂体摘出群でやや小さく，特にとの 差はシリーズ 2 でかなり明確であった。との実験から，トノサマガエルでは脳下垂体摘出後 40 日では精畄組織は摘出の影響よりも飼育の影響を強くうけており，また摘出の影響には季節差 があるととが明らかとなった。摘出は精原細胞の増殖を抑制するが，形成された精子の維持に は影響は認めら机なかった。従来の報告で無尾類における脳下垂体摘出の結果が必らずしも一 致していないのは, 種による差と共に, 摘出時の精子形成活性度・飼育環境・飼育期間なよ゙の

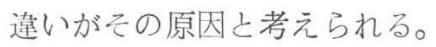
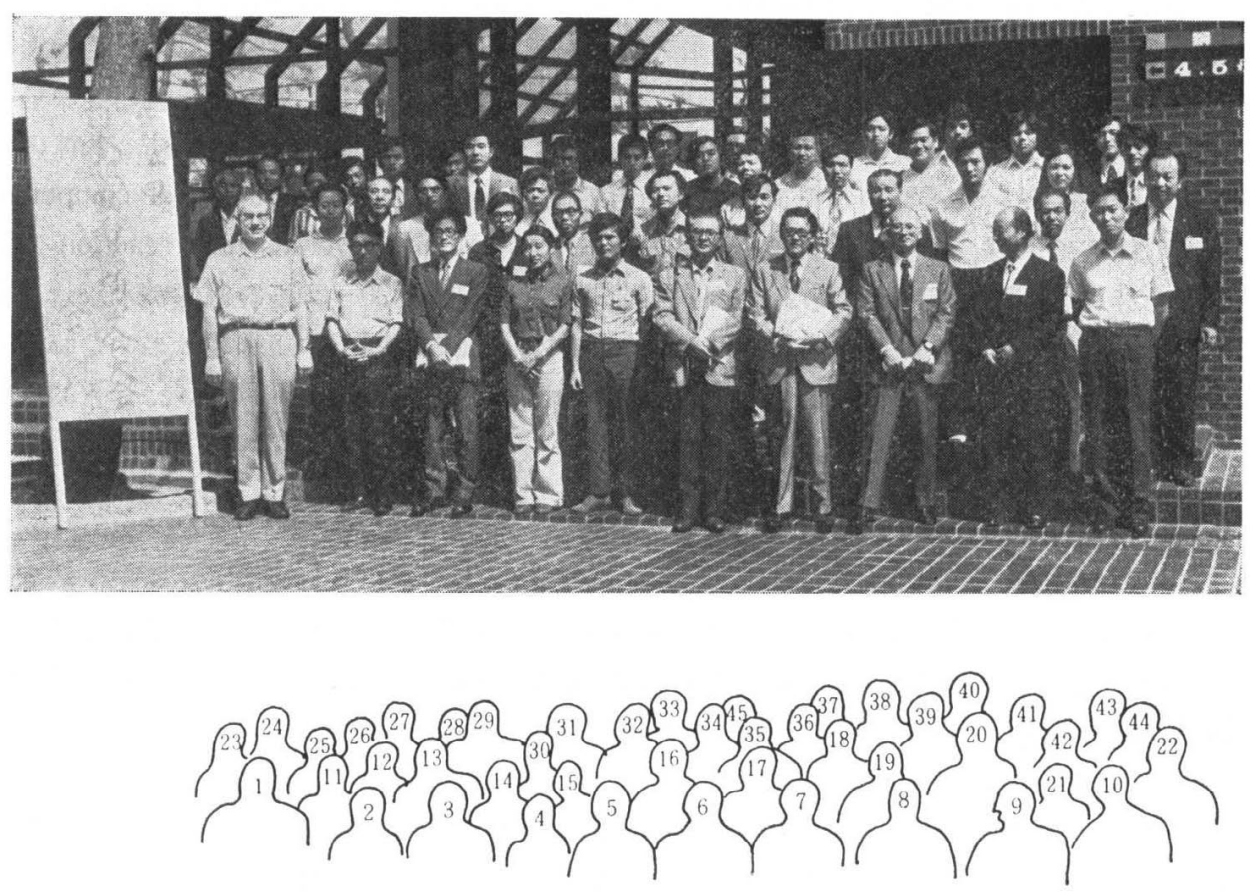

1 ゴリス・ リチャード

2 柴田 敏隆

3 柴田 保彦

4 丸い一子

5 当川昌直

6 小田幸平

7 長浜 漂

8 小川 辰之

9 深田 祝

10 杵洲謙三郎
11 原 幸治 21 -

12 照屋 寛善 13 三島 章義

14 -

15 大津:

16 疋田

17 石原 重厚

18 伊沢 信博

19 三井 貞明

20 梅津 清恭
31 桑原

22 吉岡 敏雄 32 33 北見 侹彦 $43-$

24 本間 義治

34 松井正文

35 -

36 岩沢久彰

27 佐々木邦雄

28 解良芳夫

29 吉田 朝啓

30 网俊樹
38 山本 憲史

$39-$

40 引田幸伸 
2. イモリにおける縦体結合病

杵淵謙二郎 (巻高校)

The telobiotic intoxication in the newt, Cynops p. pyrrhogaster. Kenjiro Kinehuchi (Maki High School)

一般に高等動物のマウスやラッテでは，組織適合因子の異った系統間で， 2 個体を並体結合 すると抗体産生機構に障害が起こり，並体結合病が起きることが知られている。しかし，下等 冾椎動物についててのような研究はあまりされていない。そこで，イモリの成体を用い 2 個体 の縦体結合を行い病理症状を観察した。中毒症状の期間は 20〜140日の長期にわたり，その症 状には貧血・結合部の炎症・飢餓による衰弱・体色の明調化等であり，マウス・ラッテの結合 にみられる多血球症は観察されなかった。また，中毒からの回復には早い時期の分離が有效で 苏る。組織学的には, 肝蔵の白血球造成の低下・食作なうクッパー細胞の增加, 脾蔵において は皮腐の繊維化・赤血球造成の低下がみられた。腎蔵では好塩基球の減少・核濃縮の増加が観 察された。結合個体の死亡は30〜70日に集中した。これは皮膚片の 1 次移植の生着期間の分布 上よく似ている。てれらの点と, 上記の死亡前の症状および組織学的観察より, 結合個体の死 亡の直接の原因は結合部を経由してそれぞれ相手個体に転移した Immunological competent cell がその体内で増殖し受与者の組織を攻撃する。いわゆる Graft versus host reactionによ るものであることを意昧する。一方, 結合状態を継続した場合約 $20 〜 30 \% の$ 個体が半永的（半 年以上）に生存し続ける事実はてれらの結合同志の間の組織適合因子の組合わせと，これらの 死亡する場合の結合同志の間には遺伝因子の組合わせに関してなんらかの量的ないし質的な相 違が存在するもの上思われる。

\section{3. 新渴地方へ漂着したウミヘビとウミガメの記録}

北見健彦・本間義治（新潟大・理・臨海）・吉江紀夫（日本崡大・新潟・解剖）

Records of the marine reptiles in adjacent waters of Niigata and Sado Island, based partially on the old documents. Takehiko Kitami, Yoshiharu Honma (Niigata Univ.) and Sumio Yoshie (Nippon Dental College, Niigata)

主として冬期に，熱帯ないし車熱帯系や，時には寒帯系の動物が日本海に流入し，山陰地方 から北海道南部にわたる沿岸各地に漂着する現象はよく知られている。とてろが，てれら漂泳 動物の生理や成熟状態に関する資料は至って少ない。そこでわたくしたちは, 珍稀焦の紐体類 （サケガシラ・テンガイハタ・リュウグウノッカイ）や堅皮類（アミモンガラ）について，漂 着記録を蒐集する一方, 体内諸器官の組織学的検索を進め, 生活形を推定した (Tamura and Honma, 1971, 1972; 本間, 1973; Honma et al., 1973; 千葉・吉江・本問, 1974)。また, 近 年の新溜・佐渡近海における海産爬虫類の漂着例とその傾向についても記録を整理し（本間， 1975 ; 本間・北見, 1970), 珍稀なヒメウミガメの諸蔵器を組織学的に観察した結果も発表し た (小川・吉江・本間, 1974; Honma and Yoshie, 1975)。今回は, 対馬海流により運搬され た暖海系動物の分散の傾向に深いかかわり合いをむつ北西季節風の吹寄せ現象を，よりよく把 握するてとを意図した。そこで，江戸䏯代の佐渡奉行所等に残された資料，たとえば佐渡年代 記や传渡名勝志などに載せられた記録も拾い，新暦に直して整理してみた。その結果，現在ま でに新溜県沿岸で採捕された海産爬虫類は, オサガメ・アオウミガメ・アカウミガメ・ヒメウ ミガメ・タイマイ・セグロウミへビ・エラブウミへビ・マダラウミへビの 8 種である。て扎ら 
のうち，ウミへビ類は11〜12月に，タイマイやオサガメは $1 \sim 2$ 月に捕えられたものが多く， 卓越した北西の季節風によって海岸へ打揚げられたてとが分った。一方，春から秋に得られた 個体は沖合で手網で掬われたり，定置網に罹網したものである。てのような採捕時における海 況ないし気象条件の相違は興味深い。また，へビ類とカメ類との間にみられる漂着時期や，山 陰地方と本県および山形県（杉原，1968）との採捕時期の差異なども注目に值する。

\section{Iguana iguana の舌についての組織学的研究（第 2 報）}

梅津清恭 (日本䒠大・第 2 解㨽)

A histological study of Iguana iguana tongue. Kiyoyasu Umezu (Nippon Dental College) 第 1 報に於いてはイグアナの舌のへマトキシリン染色に依る組織学的形状について発表しま したが，今回は更にアザン染色を施こし鏡見し新知見を得たので発表致します。乳䫓は舌尖端 より舌根部に亘る舌背に多数見られ, 其の形態は舌尖端約 $\frac{1}{4} に$ 於いては有廓, 葉状乳頭様な観 を呈し, 重層扁平上皮に依り覆われている。舌背中央部では系状乳頭様で極㤷简が梁く, 舌根部に至るに従い陰窩が浅く成り葉状, 咠状乳頭に形態が近似する。其の陰窩内は粘液によ り充され，上皮は円柱上皮で覆われ腺上皮の様である。下層の舌筋は横絞筋で明暗二帯が明膫 に交互に相重っており, 所々で分岐している。又, 舌骨は硝子軟骨で, 軟骨細胞は楕円形で, 全んどが 2 個又は 3 個相接し，対向面が比較的扁平な形状を呈している。舌底の中央部付近よ り舌根に至る部分に腺組織が見出されたが, 粘液腺様であり, その内部は蜂巣状の形を成し舌 根部に至るに従い大きく成り，舌根の切込み部に排導管様を有し外之交通している。

\section{Iguana iguana の歯牙について（第 3 報）}

蔡 宗憲 (日本幽大・第 2 解剖)

A histological study of the tooth of Iguana iguana. Chai chung-hsien (Nippon Dental College)

雨牙象牙質中の象牙細管は歯牙表層に行くに従い樹状に分枝し互に連絡している。エナメル 質直下の象牙質は石灰化が強く, 象牙細管よりはやや太い管腔がエナメル象牙境迄数本入り込 んでいる。䨑牙表面電子顕微鏡に於ける所見では雬冠相当部を覆っているエナメル質は小柱の 形及び大きさは不定で排列も不規則であり，又エナメル質表層には管腔及び溝之思われるもの が多数存在しているのが認められる。又エナメル質と象牙質の境は直線でなく不規則な波状を 呈している。

\section{Gerrhonotus multicarinatus の舌について（第 2 報）}

岡 和雄 (日本雨大・第 2 解剖)

A histological study of the tongue of Gerrhonotus multicarinatus. Kazuo Oka (Nippon Dental College)

一昨年度の当学会に於いて Gerrhonotus multicarinatus の舌の肉眼的形態及び H.一E. 染色 切片による鏡見から乳頭, その他組織構造上の所見について発表したが今回更に Azan 染色, Weigert の Resorcin-fuchsin 法に H.-E. の後染色を施したもの，van-Gieson 染色なよ゙を 加え前回解明出来なかった種々の疑問点及び新知見に得たので，乙てで第II 報として発表した。 その結果として，(1)乳頭は舌全長 $\frac{1}{2}$ 位の舌尖よりの舌背部及び舌下部に認めら机る。中央部に 
近い部の吉背では系状様乳頭，舌下では葉状様乳頭の形態を呈している。(2)舌全体の固有層は 菲薄で方る。(3)舌背部の乳頭内にはかなりの筋綿維が認められ，中央部の糸状様乳頭は特に良 く認められ，乳頭自体に運動性がある梯に思われる。(4)舌背中央部に多く見られる長い系状様 乳江部の上皮は腺上皮である。(5)舌の大きさに比較して非常に太い良く発達した神経線維束が

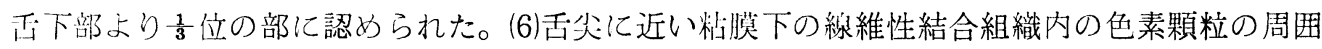
に多数の神経終末装置と疑わ机る細胞体が認妨られた。

\section{Gerrhonotus multicarinatus の歯牙について（第 3 報）}

伊沢信博 (日本崡大・第 2 解剖)

A histological study of the tooth of Gerrhonotus malticarinatus. Nobuhiro Izawa (Nippon Dental College)

米才:の表層及び䨤牙を顎骨に付着した状態で樹脂に包埋し煩舌的に中央から䋛断しその断面 のレプリカを之ってそれぞれ電子顕微鏡にて観察を行なった。蒾冠部を履っているエナメルは エナメル小柱に相当する部分の表面像はヒトの場合魚のウ口コ状に形，大きさ，排列が一定し ているが，Gerrhonotus multicarinatus の蒾牙では形む大きさも大小不同であり排列む一定の 型を示さずバラバラに並んでいる。更に表層には管理や溝と思利るものが多数存在しており， その管腔の周囲は比較的，形，大きさの同じ様な小柱様のエナメル質の基質が取り巻いている。 又断面像では小柱様の基質が象牙質から歯牙表面に向ってほぼ平行に排列しているのが認めら 记この途中途中に小柱の長軸に直角に竹のふしの様な横紋が存在する。これは石灰化の違いが 表われたのであるうと推測される。

\section{8. カナヘビ交尾の 1 観察例}

山本慧史 (加古川)

An observation on copulation of the lizard, Takydromus tachydromoides. Kenji Yamamoto (Kakogawa)

兵庫県加古川市近郊の草地で採集したカナヘビ 1 対（雄体長 $13 \mathrm{~cm}$, 雌 $15 \mathrm{~cm}$ ) をアクリル谷 器 $(30 \times 44 \mathrm{~cm})$ に入れ室内に置いて観察していたところ，1975年 6 月 5 日夜交尾を目撃した。 当日は昙り小雨, 気温 $25^{\circ} \mathrm{C}$, 湿度 $85 \%$ 。22時 02 分容器の上方 $1 \mathrm{~m}$ のところに $60 \mathrm{~W}$ 電灯をつけ たところ，22時10分雄が雌の頚部の皮䵇を咬み容器内を引きずりまわし，瓦いに捻転して交尾 行動を開始した。雄は 2 本劣る陰茎のうち 1 本を雌の排泄口内梁くに插入した。雌雄の捻転行 為は $3 \sim 5$ 回, 約 30 分にして両者は離れた。雄の陰茎はその後約15分して縮小し尾基部内に 入ってみえななった。

\section{9. カナヘビ・トカゲ・ヤモリの鳞の表面微細構造}

石原重厚 (宗都教育大)

The ultrastructure of scale surface of lizards: Takydromus tachydromoides, Eumeces latiscutatus and Gekko japonicus. Shigeatsu Ishihara (Kyoto Kyoiku Univ.)

日本産のカナヘビ・トカゲ・ヤモリの脱皮した表皮 (Slough) を光学顕微鏡と走查㧘子顕微 鏡により表面微細構造を観察した。材料は飼育した個体より採集して,デシケーター保存した ものを使用した。光学影微鏡標本は直接スライドグラスにマウントして検鏡した。走査電子顕

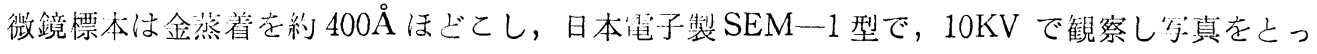


た。観察した個所は胴部背腹面・頭部・尾部・脚部におよぶ。

〈カナへビ〉 すべての鱗の全表面に共通した波状のすじ模梯がある。その間隔は背面では $1.7 \sim 5.0 \mu$ 平均 $2.8 \mu$, 腹面で $2.0 \sim 4.8 \mu$ 平均 $3.2 \mu$, 耳刻部で $2.8 \sim 5.6 \mu$ 平均 $3.5 \mu$ と各部によっ て異なる。背面・側面の鱗は起伏があり，隆条から発する沢山の棱線に直角に波状のすじが市 るので網状模様を呈しうねっている。腹面では䚬に起伏がなく平板であるため波状のすじはう ねるこよはない。また，鱗の裏面全体にタイルをはったような模椂がみられる。背面ではその タイル状の一つの大きさは $31.9 \sim 38.9 \mu$ 平均 $34.7 \mu \times 12.5 \sim 19.4 \mu$ 平均 $13.9 \mu$ であるその中に 短軸に平行に巾 $1.2 \sim 3.2$ 平均 $2 \mu$ のひだが並んでいる。腹面では巾は変らないが長さが $300 \mu$ に達するものがあり，隣のもの之くっついて枝状になっているものが多い。

〈トカゲ〉 背面・腹面の鱗の大きさ・形・表面のなめらかさなよ゙，ほぼ同じ。異なる所は背 面の鱗には色素が多く色がついている。表面に同心円状にノコギリ状の線が全面にある。先端 部では $4.5 \sim 13.0 \mu$ 平均. $9 \mu$ 間隔に層状をなしている。基部に行くにしたがって $5.5 \sim 23.0 \mu$ 平 均 $13 \mu$ 間隔になり，ノコギリ状の突起がなくなる。その雨の形は円錐形のものを少し押しつけ

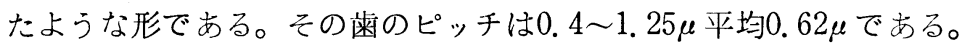

〈ヤモリ〉 鱗および鱗間の表面全体に剛毛状の突起がある。突起の長さは, 背面で $0.4 \sim 2.5 \mu$ 平均 $1.5 \mu$ ，腹面で $2.5 \sim 5.0 \mu$ 平均 $3 \mu$ ，鱗間では $1.5 \sim 2.5 \mu$ 平均 $2.0 \mu$ で京った。胴背面と尾の 腹面に直径平均 $22.7 \mu$ の円形の基部から長さ約 $25 \mu$ の 1 本の太い剛毛のある器官がみつかる。 1 鱗に平均 $2 \sim 3$ 個みられる。背面では突起が短いので, 細胞之細胞の境界がわかる線がある。

\section{0. ハプの高温致死温度測定の試み}

深田 祝（京都教育大）

An estimate of critical thermal maximum of Habu, Trimeresurus flavoviridis. Hajime Fukada (Kyoto Kyoiku Univ.)

八ブの高温致死温度を，昭和 49 年 5 月及び 10 月に名瀬保健所に於て，心電計と温度計とを用 いて测定した。脈搏数は体温が上昇するにつれて多くなるが，最高值に達すると以後急激に減 少して死亡する。この脈搏数が最高に達したときの体温を高温致死温度とみなすと，ての温度 は蛇の体調や加熱の方法によって異なるようである。蛇の体温を室温 (約 $\left.26^{\circ} \mathrm{C}\right)$ から $40^{\circ} \mathrm{C}$ に 3 時間かけて上げるとき，八ブの高温致死温度は $36^{\circ} \mathrm{C}$ となる。マムシを同じ条件で測定する 上 $39^{\circ} \mathrm{C}$ となる，またシマへビあハブより高い致死温度を示す。このとよからハブは高温には 比較的弱いといえそうである。

\section{1. イシガキトカゲの白綐線について}

Variation in the light line of Eumeces stimsoni. Masanao Toyama (Kyoto Univ.)

イシガキトカゲは，奻時に 7 本の白縦線をむつことによって 5 本の線をむつ他の近縁種と区 別される。しかし，乙の 7 本線を形成する最外側の sublateral line の明膫度にはかなりの变異 がみられるので, 石垣島・西表島産の白縦線のみられる100個体の標本を検討した。 sublateral line の状態を，〔A〕明瞭，〔B〕不明瞭・痕跡的，〔C〕欠除の三段階に分けて検討したよてろ， 〔A〕14\%，〔B]28\%，〔C〕58\% となり，完全な 7 本線をもつものは少ないとよがわかった。

〔C〕（ 5 本の線をもつもの）は，成長に伴い増加する反面，孵化後まもないものでも $40.7 \%$ の 高頻度で出現した。次に，採集地点ごよに検討したよころ，西表島第 I 山小屋（山地）では 
[A] $5.6 \%$, [B] $33.3 \% ，$ [C] $61.1 \%$, 石垣島川平 (平地) では〔A] $25.0 \%$, [B] $45.0 \%$, C】 $30.0 \%$ あっった。所検標本の体長構成はほぼ同じである。他地点で採集されたものも一括 して観察した結果，山地では，平地に比べて 7 本線個体の出現率が低いようである。なお，山 地桻のものは, 平地棲のものより lateral line が細く, また, 雄で体長が $70 \mathrm{~mm}$ 以上に達して も白縦線が明瞭に残っているものがみられた。平地棲のものは, イシガキトカゲの従来の記載 上ほぼ一致する特徴を有するが，山地棲のものは必ずしもそうではないので他種之識別する場 合には注意を要する。山地棲のものによくみられる変異がこれまで記載されなかったのは, 戦 前まで, 石坦・西表の雨島にはマラリアが蔓延し, 山地での採集が困難だったとよと関連して いるのでるうう。

\section{2. ニホントカゲにおける卯化後の頭骨の形態変化 正田 努 (京大・理・動物)}

Morphological changes in skull of the Japanese skink (Eumeces latiscutatus) after hatching. Tsutomu Hikita (Kyoto Univ.)

Taylor (1935) は镂，斑紋等の外部形質に基づき，トカゲ属 (Eumeces) 内の分類を行った。 しかし，彼は系統分類上重視されるべき頭骨の形態については検討しなかった。他方，Kingman (1932) 等は若干の種の頭骨を記載しているが，それらはごく少数の標本に基づいたもの で, 種間比較に先立って必要な種内変異の検討は全くなされていない。そてで, 演者はニホン トカゲの頭骨の形態の種内変異を, 発育・成長に伴う雌雄の差異に注目して調査した。まず, 雌雄各16個体を体長構成之骨化の程度により，O-Vの6段階に分離した。段階 $\mathrm{O}$ は率化直後, 段階 I は 1 回越冬経験, 段階II 2 回越冬経験, 段階IIIはぼ 3 回越冬経験, 段階IV,Vは 4 回以上越冬経験した個体之考えられる。化骨の度合を決定する為に，頭頂骨の縫合線の消失・ 方形骨の骨化・䫓頂骨後部の陵の発達・上部側頭空の間隙の有無・側頭部の外方へのふくらみ の発達・頬骨突起の有無に注目した。雄は段階II, 雌は段階IIIで性成熟する。性差は段階II 以 後, 次第に顕著になる。雌では幼形的特徵がかなり維持されるが, 雄では性成熟に伴い頭骨が 大きく, 頑丈になる。頭胴長に対する頭骨長の相対成長を見ると, 雄では性成熟に伴い相対成 長係数が大きくなる（危検率 $5 \%$ で有意)。しかし，雌では相対成長係数は性成熟後も変化せ ず，雄の未成熟の個体とほぼ等しい。この様に，雄の頭骨が性成熟とともに大きく，頑丈にな ることは, 繁殖期の雄成体が非常に攻撃的になり，しばしば激しい闘いを演じることと関連し ている様に思われる。なお，明瞭な性差は認められなかったが，上顎骨・米骨・翼状骨の米数 は跉段階が進むにつれて增加する傾问にある。また, 前顎骨の粜数は柃段階に関係なく, 左 3 本，右 4 本であった。

\section{3. カナヘビにおける精巣間細胞及びセルトリ細胞の微細構造}

風 俊樹 (東宗学芸大・生物)

Fine structure of testicular interstitial cells and Sertoli cells in the lizard, Takydromus tachydromoides. Toshiki Oka ('Tokyo Gakugei Univ.)

精巣間紏胞の㫣子顕微鏡的観察は, 哺乳類を中心に多くの報告がなされているが，爬虫類に 関しては，非常に数が少い。また，セルトリ細胞の微細構造についても，爬虫類では，コモ千

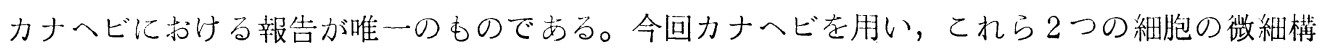


造の観察を行った。本種における精喿間細胞は, 哺乳類等に比較して, あまり顕著な発達を示 さず，しばしば血管及びリンパ管の周囲に細胞群をなして出現する。間細胞には，いわゆる暗 細胞之明細胞上の別が認められ，乙れらの笔子密度の差は, 主に小胞体の分布密度之その電子 密度の差に由来する。すなおち, 暗細胞は, 高電子密度の滑面小胞体が非常に密に分布してお り, 一方, 明細胞においては, 小胞体の分布は比較的粗で, 大型の空胞様構造が多数観察され る。この空胞の起源は, 主よして滑面小胞体にあると想われる。明細胞の出現頻度は, 春季に 高いようである。ミトコンドリアのクリステは，ラメラ状の外に，小管状を呈するものも観察 される。また, 細胞質中には, 多数の脂肘榈も存在する。以上のことからして, 本細胞におけ る活発なステロイド合成が示唆される。なお明暗両細胞の中間型をなす細胞も認められ，乙れ ら細胞形態の差は, 細胞の生理状態の差に由来するもの之思われる。セルトリ細胞は他の脊椎 動物におりる観察と同様, 基底部に核を有する大型の細胞で, その遊離端は精細管内腔に達し ている。精子先体を包む部分の細胞質は, 非常に特殊化しており, 細胞小器官の発達は認めら れない。また, 遊離端に近い細胞質中には, 多数の滑面小胞体, 空胞, グリコゲン顆粒等が観 察される。これに対し, 基底部の細胞質中には, 粗面小胞体・ゴルジ装置が存在し, 特有な形 態の類結晶も認められる。この類結晶は限界膜を有し, 多数の微細繊維から構成されており, 肧体及び奻体のセルトリ細胞に出現しないととから, 性的成熟亡何等かの関係があるものと思 われる。

14. シロヘビの疾病に関する研究 (3) 三島章義・沢井芳男 (日本蛇研) ・本間 学 (群大)

Pathological conditions in aibino Elaphe climacophora. Shogi Mishima, Yoshio Sawai (Japan Snake Center) and Manabu Homma (Gumma Univ.)

岩国産シロへビの疾患については，すでにその一部を報告したが (三島外，1974），その後 さらに飼育中慨を椇らなくなって死亡したシロへビ成蛇の 3 例についての病理学的検索の結果 を報告する。第 1 例は日本蛇研で飼育していた雄の成蛇で, 1975年 6 月 2 日に死亡した個体で 尚る。外観に異状は認女られなかったが，死亡する2 ケ月位前から摄食しなくなっていた。剖 見の結果, 胆管・胆導管には膿汁が充満し, 胆囊の胆大が認められた。病理組織学的検索の結 果, 蓄膿を伴う慢性胆囊炎・胆管及び総胆管の炎症・肝内胆管炎および胆管炎性膿瘍・慢性十

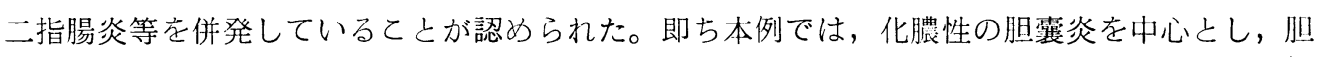
管系全体に斿たる炎症によって死亡したものと考えられる。

第 2 例む日本蛇研で飼青中，1975年 6 月 6 日に死亡した雌の成蛇である。乙の例も外見上の 異状は認められなかったが, 剖検の結果, 口腔内には粘液がたまり, 肺は充血して肺腔内には 虾様物質が充たされ，胆囊は極端な水腫性の肥大を呈し（径 $82 \times 48 \mathrm{~mm})$, さらに大腸部には第 孔があって，大きな慨様物質が腹腔内に押し出されて硬結し，腹膜炎の様相を示していた。病 理組織学的所見では, 第孔性腹膜炎・感染性脾臓炎・朋膿陽・水腫性胆囊炎および肺炎等を併 発していた。

即ち本例では, 第孔性の腹膜炎を起てし，二次的に脾・胆・肝および肺等に炎症を併発し， 末期には敗血症を起しして死ししたものと考えられる。

第 3 例は, 岩国白蛇保存会の飼育場で飼育されていた雄の成蛇で，全身に痂皮性の皮膚炎を 起して衰弱死した個体である。外部所見は奻蛇にみられた真菌のAspelgillusによる泇皮形成 
性皮膚疾患に酷似していた。病理組織学的所見でも，肺・朋・脾などの臟器には著変は認めら れず，皮虐の瘀皮形成部は表皮がくずれ，Aspelgillus と思われる真菌類の菌系が炎症性渗出 物之共に皮膚表面に付着しており，奻蛇にみられた皮膚疾患（三島外，1974）之全く同じで市 ることが判明した。てのような真菌類により泇皮を形成する皮痛病が，成蛇に発見されたのは 初めてである。

\section{5. 東南アジアの爬虫両棲類展示}

原 幸治 (上野動物秱)

Herpetological Exhibitions of South East Asia. Koji Hara (Ueno Zoo)

1975年 3 月13〜26日に，インドネシア (ジャワ島)・シンガポール・西マレーシア・タイ・ ホンコンの動物園を中心とした17の展示施設を見てまわった。爬虫類を全く見せていないホン コン動植物園を除くよ，大なり小なりの爬虫コレクションを持っていた。展示施設そのむのは かなり立派なものもあり，部分的には東南アジア以外の国之較べても遜色はない。問題は収容 動物の質である。種類数は 45 種よいうのが最高で市った。コレクションは, 自国産が大部分で, その他に少し他の東南アジア産のと，それ以外の外国産の種類からなっていた。自国の種を展 示するのは重要だが，集め方の偏りから判断して，自国の動物の重視というょり，手に入らな いから自国産の種に偏っていると思われた。収容されている大部分は日本で見られるもので, 目新しい種を見た時にうける喜びに欠け，種の同定はいまひとつという感じで，ラベルのつい ていないもの，ちがっているものが多く，てれらがかさなって迫力が感じられなかった。

カメは集めてあると感じたのは一園だけ。ワニは特殊な施設を除くとどてにもいたが，大部 分は同じ種類。トカゲはオオトカゲを除くとごくわずか。へビも多いとはいいがたく，地中生 や水生のへビは殆んよ゙見られなかった。両棲類は 5 つの施設で見た。1つはシンガポールのナ ショナルミュージアムで, 展示してあると感じた唯一のものである。他はいずれあ 1 種だけで, 3 施設では䬣かたまたまおいたというものであった。シンガポールの博物館は東南アジアとい う面から見れば別格であるから，両棲類展示はまだ緒にもついていないと言えそうである。

\section{6. ヒキガエルとトノサマガエルの温度に対する反応}

丸山一子 (京大・理・動物)

Physiological response to temperature in the Japanese toad and pond frog. Kazuko Maruyama (Kyoto Univ.)

咽頭呼吸運動数を示標として, 恒温箱内で, 温度に対するヒキガエルとトノサマガエルの反 応を比較した。また，トノサマガエルについて成熟個体と未成熟個体の比較を行った。ヒキガ エルは紀伊半島大台ケ原より，トノサマガエルは京都市宝ケ池より採集したものを用いた。温 度は $5^{\circ} \mathrm{C}$ から $20^{\circ} \mathrm{C}$ まで $2.5^{\circ} \mathrm{C}$ おきに設定し，トノサマガエル成熟個体については, $30^{\circ} \mathrm{C} ま$ で測定した。各温度に 2 時間以上静置した後，20〜30回の咽頭呼吸運動に要する時間を計测し， 単位時間当りの呼吸数に換算した。測定の結果, 高温域では体温が変化しても呼吸数に大きな 変化はみられなかったが，トノサマガエル成熟個体で $20^{\circ} \mathrm{C}$, トノサマガエル末成熟個体および

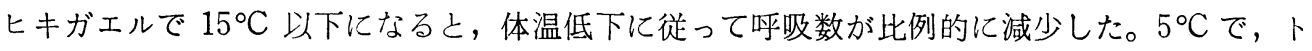
ノサマガエルは成熟個体・未成熟個体とも完全に咽頭呼吸運動を停止したが，ヒキガエルでは 停止に至らなかった。また，野外での観察の結果は以下のようであった。京都において，産卵 のために移動中のヒキガエルの体温を測定したところ， $5.1 \sim 8.5^{\circ} \mathrm{C}$ であったのに対し，尾外 
飼育中のトノサマガエルは同時期に $7 . \overline{2} 8.6^{\circ} \mathrm{C}$ の体温走示しながら，まだ土の中で冬眠して いた。この上きの体温は, カエルの居た場所の地温にほぼ等しかった。カエルでは, 未成熟個 体汢成熟個体より遅く冬胙に入るこいわれているが，宗都市大原のトノサマガエルについても 同様の結果が得ら机ている。

以上の諸点から考えると，ヒキガエルはトノサマガエルより，トノサマガエル未成熟個体は 成熟個体より，全般的に低い温度で生理的・行動的な変化を起こしており，より低い温度での 活動に適した生理的性質を持っているのではないかと思われる。

\section{7. 南大東島から記録されたオオヒキガエルについて}

松井正文 (京大・理・動物)

On the record of the giant toad, Bufo marinus, from Minami-Daitojima, Ryukyu Archipelago. Masafumi Matsui (Kyoto Univ.)

本誌報文欄を参照のとよ。

\section{8. 飼育下のトノサマガエルの死亡について}

津田義包（東京）

On the death of captive frogs. Yoshikane Tsuda (Tokyo)

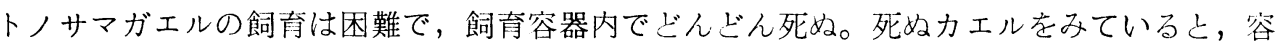
器の中央で 4 肢を伸ばして死好の上, 容器の隅で 4 肢を維めてうずくまり固くなって死好も の上 2 通りがある。前者の場合は体はすぐ腐るが，後者の場合は腐らないで，体は干物のよう になってコチコチになるようである。

\section{Sauria ; Lizards の歯牙について}

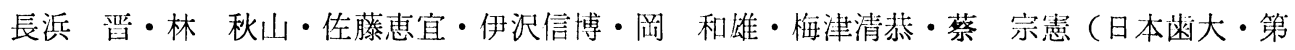
2 解剖)

On the teeth of Sauria. Susumu Nagahama, Shuzen Rin, Yoshinori Sato, Nobuhiro Izawa, Kazuo Oka, Kiyoyasu Umezu, and Chung-hsien Chai (Nippon Dental College)

トカゲ類10種 Family Gekkonidae, Family Agamidae, Family Chamaeleonidae, Family Iguanidae, Family Teiidae, Family Lacertidae, Family Scincidae, Family Anguidae, Family Helodermatidae, Family Varanidae, 総数48個体の上顎並に下顎に存在する籶牙数について前 回49年度爬虫両生類学会に於て発表したものに追加して各種のトカゲを解剖し, 主としてそれ 等の粗牙数を検势して興味ある事奏が判明したので，前回の発表に追加して発表する。

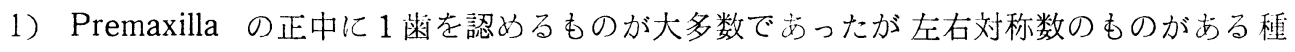
のものには存在するようである。

2) Premaxilla には正中 1 潾の他に左右刘称的に $1 \sim 15$ 刘の米邪走有する。

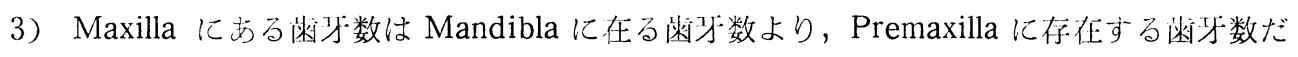
け多いか，或いは正中 1 粜だけ多いむのが認められる。

4）交換する次期菌芽は現存幽牙のやや下位の舌側，口蓋側面上皮下に並んで前出を待つ形 態を取っている。

5）次期交換未萠出米牙は現存迷牙の料䯣汇突入して発育しつつある像は認められない。 